\title{
Threats to Security Posed by ISIS in Syria: A Human Security Approach
}

\author{
Lee-Ann Louw and Hendrik Johannes Lubbe* \\ Department of Law, North-West University, Potchefstroom, South Africa \\ * Corresponding author: E-Mail: hein.lubbe@nwu.ac.za
}

Submitted: 29 July 2016 | In revised form: 31 January 2017 | Accepted: 2 February 2017 | Published: 30 March 2017

\begin{abstract}
The civil war in Syria coupled with the attacks by ISIS, has resulted in one of the largest humanitarian crises since World War II. Although international efforts have resulted in regaining control of important cities, these military approaches have escalated and inflamed the violence of which innocent civilians bear the consequences. The continuing violence and resulting threats or insecurities negatively affect the lives, freedom, dignity and development of the people to name but a few. For that reason, the aim is to explore the applicability of a human security approach to the conflict in Syria that focuses on, among other aspects, minimising violence, mitigating the effects of the conflict, protecting people, restoring peace and eliminating the grounds that resulted in the development of these conditions in the first place.
\end{abstract}

Keywords: civil war; human security; human rights; ISIS; Syria

\section{Background \& Introduction}

The Arab Spring of 2011, which originated in Tunisia and soon spread to neighbouring North African countries and to the Middle East, consisted of a range of protests against oppressive governments to oust dictators [1]. In Syria these protests were suppressed by the government with the implementation of violent methods [2,3] such as: opening fire on protesting crowds; the use of landmines and cluster bombs; and, the arrest of innocent people who were later detained, tortured and women were sexually abused [3,4]. This violence soon escalated into a full-blown civil war [2] as armed opposition groups openly started to confront state forces.[4] In turn, the state forces intensified the ferocity of their methods by using chemical weapons and gathering their prisoners in starvation camps [5]. These conditions have resulted in, among other things, the destabilisation of security in Syria [6] that established the perfect environment for extremist groups such as ISIS, which originated in Iraq, [7] to infiltrate Syrian territory [8].

ISIS is a Sunni Muslim group and an affiliate of the Al-Qaeda terrorist organisation [8-12]. This group believes that their interpretation of the holy book of Islam (Quran) should prevail, and they will pursue the enforcement of their version even if this means resorting to drastic measures that they consider to be warranted by their jihad or "holy war"-measures such as car and suicide bombings, kidnapping, rape and beheadings [13,14]. The conflict has already resulted in the internal displacement of over 7.6 million Syrians and more than 3.2 million Iraqis [15]. As a result over 4.2 million Syrians [16] and more than 180000 Iraqis [17] are currently seeking asylum [18,19].

The activities of the Syrian government coupled with the attacks by ISIS have contributed to what is being described as one of the largest humanitarian crises since World War II, [20] and the question the international community has since 
been confronted with is whether third states can or should intervene in order to protect the people, as the Syrian government is clearly unable or unwilling to stop or prevent these abuses from occurring within its territory [21]. As a result of this crisis a US-led coalition was formed with the primary purpose of conducting airstrikes in both Syria and Iraq in order to eliminate ISIS [22-24]. The coalition, which initially consisted of five members [23], is now composed of more than 60 countries [23,24]. By April 2016 the coalition had conducted 11,308 strikes, managing to destroy a great deal of ISIS equipment [25]. They have also crippled ISIS activities and driven members of this organisation from certain areas which were under their control. In addition, Iraq and Kurdistan have sent troops to Syria in order to physically confront and defeat ISIS [13]. US personnel have also been dispatched to these areas with the purpose of training and equipping these forces [26].

Although these international efforts have resulted in regaining control of important cities, these military approaches have escalated and inflamed the violence, of which innocent civilians bear the consequences. The continuing violence and the resulting threats or insecurities negatively affect the lives, freedom, dignity and development of the people, to name but a few of the deleterious social and individual effects [27,28]. For that reason, the aim of this article is to explore the applicability of a human security approach to the conflict in Syria that focuses among other aspects on minimising violence [29], mitigating the effects of the conflict [27,30], protecting people [29], restoring peace and eliminating the grounds that resulted in the development of these conditions in the first place [27].

To achieve this aim the concept of human security will firstly be explained in brief terms in paragraph 2 . This will be done with specific reference to the characteristics of human security in the context of Syria and Iraq, the implementation phases of a human security programme in general, an specific examples of situations where such a programme has been implemented. Paragraph 3 will identify possible threats to human security posed by ISIS and explore responses thereto, where after some concluding remarks will be made in paragraph 4.

\section{Human Security}

The international community was introduced to the concept of human security with the release of the Human Development Report by the United Nations Development Programme (UNDP) [31] "under the guidance of Dr. Mahbub ul Haq" [32]. Human security as defined by the Commission on Human Security (CHS) [27,28,33-38], aims to protect the vital core of all human lives in ways that enhance human freedoms [39] and human development [40]. It focuses on protecting the fundamental freedoms that are the essence of life, meaning that it protects people from critical and pervasive threats and situations [41]. It employs processes that build on people's strengths and aspirations by creating political, social, environmental, economic, military and cultural systems that together provide people with the building blocks for survival, livelihood and dignity.

\subsection{The Characteristics of Human Security in Context}

Human security is people-centered, multi-sectoral, comprehensive, context-specific and prevention-orientated [27]. The CHS has emphasised the importance of focussing on human security as it can be used to effectively respond to multifaceted insecurities such as terrorism of which the impact and effects are not confined to a single territory $[27,28]$.

As revealed by the events of the Arab Spring, state actors seem to think that it is acceptable to violate human rights in order to uphold state security $[6,42]$. However, as indicated by the Arab Human Development Report (AHDR), state security and human security are intertwined, as "human security is a condition for the achievement of state security" $[6,43]$. Consequently, the concept of human security primarily focuses on protecting the integral worth of people against insecurities rather than protecting the state [30]. People are placed at the centre of this response and it focuses on the circumstances that threaten the well-being and survival of the people $[28,30,31,38,39]$. As a result, the promotion of human security does not lead to a military response or defence, instead it promotes and develops aspects such as human rights and economic conditions [18,31].

Focusing on the security of people entails that human rights be of primary concern and therefore take precedence over state sovereignty [29]. As human security aims to promote equity, solidarity, freedom and dignity, the people are seen as "equal actors to the state in international relations" [30]. Furthermore, human security is multi-sectoral in that it recognises a range of threats or insecurities that can be connected and that can affect the stability of neighbouring states as well as whole regions [28,32]. These can include threats to economic, environmental, food, health, personal, community and political security [28] due to "the loss of access to jobs, health care and social welfare" and "terrorism, extremism, displacement and human rights violations" [30].

Although the economic, environmental, food and health security of the Syrian and Iraqi population are also affected by the conflicts in these areas, for purposes of this note emphasis will be placed on the threats posed to personal, community and political security due to violence, terrorism, religious and ethnic tensions, human rights abuses and political exclusion [28,30,37].

Due to the fact that these insecurities are "interconnected" and create a "domino effect" [30], human security also recognises that a comprehensive response recognising the importance of cooperation from both the community and the state is essential to deal with these threats $[27,28]$. With reference to the airstrikes in both Syria and Iraq in order to eliminate the threats posed to the population [22-24], Tadjbakhsh and Chenoy argue that: "Military solutions should not be used to deal with insecurities, but rather comprehensive strategies that abide by the promises of development and promotion of human rights. It also promotes public policy and state building efforts that reduce the triggering of such threats on the first place" [30].

In contrast, Kees Homan argues that human security does not exclude the use of force as a short-term response $[29,44]$. 
Instead, military operations and human security programmes should be carried out simultaneously [29]. Military forces can assist in realising human security by "shifting operations of warfare to that of law enforcement, and minimising the amount of force used in order to protect people against casualties" [29]. Human security also takes into account that threats or insecurities can differ from state to state, and therefore the context must be taken into account when considering a relevant response [28]. Due to the fact that human security is a long-term response [44], it targets the root causes of these insecurities and focuses on eliminating the conditions that result in the development of these threats with the view to preventing them from recurring in the future $[28,45]$.

Human rights, freedoms and dignity are secured by focussing on empowering and protecting the people who are affected by these insecurities [27,28]. An empowerment framework entails a bottom-up approach which focuses on developing strategies that can encourage the community to correctly decide on their future. A protection framework, on the other hand, is a top-down approach that acknowledges the existence of natural threats which cannot be controlled. As a result, people must be protected in a "systematic, comprehensive and preventable way" [28]. As explained by the UN Human Security Unit, by using top-down processes such as good governance combined with bottom-up methods through which people are informed about their rights and responsibilities, a human security framework can warrant capacity building and coherence [45].

\subsection{The Implementation of a Human Security Programme}

A human security programme is implemented through different phases during which different responding strategies are identified [46]. These strategies must take into account certain goals and tasks which need to be accomplished in order to "ensure the integrity of the programme" [47].

Phase I entails analysing, mapping and planning. During this stage, the particular threats or insecurities faced by the community are identified through the process of data collection. At this stage, the root causes of these threats and the needs and vulnerabilities of the community are also established. The data collected is then captured on the human security needs, vulnerabilities and capacity matrix table. This table portrays the threats, together with the local, district and national needs and vulnerabilities and it also reflects the capacities and resources of the community. The process of mapping is important as it reveals priorities on which strategies should be developed. Consequently, these strategies focus on enhancing protection and empowerment as well as on "mitigating and preventing the re-occurrence of these insecurities".

Phase II is the implementation stage. Participatory processes are developed which focuses on building the capacity of communities and state institutions. As identified by the Human Security Unit, these processes entail presenting the programme to the community, allowing feedback, appointing a committee to implement the programme, the use of local resources to prevent competition and economic detriment, and ensuring the establishment of monitoring and reporting mechanisms.

Phase III is the impact assessment stage and the importance of this stage is to establish if the programme focuses on human insecurities while at the same time avoiding negative externalities. Based on this and by referring to lessons learnt from previous programmes, the human security programme can constantly be improved.

\subsection{DRC and Kosovo as Examples of Stability Achieved by Using a Human Security Programme [48]}

With regards to the continuing violence in the DRC [49], a human security project or programme has been identified as the best way to "bridge the gap between emergency assistance and medium- to long-term developments" if "it focuses on protecting people from critical and pervasive threats and empowers them to build on their own strengths and aspirations" [28]. As explained earlier, human security is implemented by empowering and protecting the people; in this specific context, the human security programme has been designed to empower the people by providing job opportunities, strengthening the ability of the government to provide services such as health care and education and encouraging local production. The protection of people has been further ensured by establishing mechanisms and committees that could identify threats and strengthen the capacities and abilities of the police services.

With regards to the situation in Kosovo [50,51], the UN Human Security Unit has recognised that the current tensions could not be alleviated through piecemeal responses but instead required a comprehensive and integrated approach based on human security. However, due to the poor infrastructures and division between the different ethnic communities that exist in Kosovo as a result of historical conflict, the achievement of human security has been described as challenging. Nevertheless, the human security programme designed for this area focuses on strengthening the capacities of the authorities to provide health care, education and other important social services. Furthermore, it focuses on enhancing the quality of these services by working with the healthcare facilities and schools. Also, as a means of addressing poverty, career opportunities are being created and people are encouraged to work even if the job is short-term. Because of the fact that ethnicity is the root of most problems in Kosovo [52], provision has also been made for the implementation of local programmes which deal with resolving disputes and educating different groups in order to work towards eliminate these divisions [53].

\section{ISIS, Its Threat to Human Security and Possible Responses Thereto}

As already said, ISIS is a Sunni Muslim group and an affiliate of Al-Qaeda that uses brutal tactics such as rape, beheadings, kidnappings, car and suicide bombings, crucifixions and mass 
executions [13] against Christians, Yezidis, Kurds, Shia Muslims and anyone opposed to its methods, values and ideas [14].

The struggle between Sunni and Shia Muslims originated in the difference in their belief system, as the former believes that the deceased Mohammed could be replaced by an elected individual, and the latter, on the other hand, believes that a family member of Mohammed should succeed him [54]. The selection of a non-family member as the leader of the first caliphate caused a final division between these two branches of Islam [54].

ISIS perceives members of any religion other than Sunni Islam as "infidels" and justifies its conduct by interpreting the Quran radically [55]. They believe that their interpretation should prevail and they will pursue the enforcement of their version even if it means that they should resort to drastic measures. This extreme action of implementing dogmatic, extreme values, measures and beliefs is warranted by the jihad or the "holy war" [56]. In terms of the ISIS programme, "jihad" is "an aspect of a radical, religious ideology that supports terrorism and other acts of criminal violence" [55].

As stated earlier, the continuous conflict within these areas has already resulted in the internal displacement of over 7.6 million Syrians and more than 3.2 million Iraqis [15]. As a result over 4.2 million Syrians [16] and more than 180,000 Iraqis [17] are currently seeking asylum abroad $[18,19]$. Human security focuses on the individuals within a state and therefore it can play an important role in promoting and protecting the human rights of "vulnerability and insecurity" refugees $[18,57]$. Complications related to this approach can arise, however, as there could be conflict between the interests of refugees on the one hand and the interests of the state and safety of the citizens on the other hand [18]. This specific situation is reflected by the terrorist activities which are occurring in Europe today as ISIS members infiltrate Europe by posing as refugees [58,59]. In such cases sovereignty and the protection of the interests of the citizens of the state will take precedence [18].

Human security focuses on present and evolving threats to the security, development and well-being of individuals and communities. It is also a long-term solution to the negative effects created by war. Consequently, by identifying the concrete needs of the Syrian and Iraqi population, a human security framework could effectively be implemented to "directly and positively affect the daily lives of these people" [27].

Unlike the use of force, this would have an "instant result that is mainly concerned with the root causes of these threats" [27]. If these insecurities are not eliminated and prevented in their entirety, this failure could have an effect on the long-term stability and infrastructure of Syria as well the international community, as explained by Scott Lassan [60]. Health problems would also continue to persist in this geographical area, as the government is not capable of providing adequate service delivery. Furthermore, education has been affected to such an extent by the continuous conflict that the present-day skills and decisions of the general population have already been negatively affected.
By implementing a human security programme in terms of which the Syrian and Iraqi communities are involved and encouraged to take control of their own lives and decisions, it can be ensured that the feelings of exclusion, oppression and rebelliousness that created these threats are eliminated. Such a programme would identify the needs and vulnerabilities of the people as well as the gaps between local, regional and international responses [27]. It could also "develop early warning mechanisms which are important to mitigate and prevent such threats" [27,61]. This being said, the people of both Syria and Iraq can be empowered and protected by enhancing the personal, community and political security in these areas.

By implementing mechanisms and strategies that can ensure the protection of human rights, personal security can be protected. Likewise, the instituting of processes and mechanisms that can ensure the elimination and prevention of discrimination and oppression can promote community security. Furthermore, the encouragement of good governance and punishment of wrongful acts by the state can prevent the abuse of state power and as a result enhance political security [28].

The effect of possible interventions on personal, community and political insecurities have been identified by the UN Human Security Unit [28]. With regards to personal security, police and other security officials can be properly trained to deal with such threats. The CHS has identified one possible advantage of such an intervention as being freedom from fear. However, a possible disadvantage is that the shifting of state power could result in instability. A strategy to protect and enhance community security could include demilitarisation, and although security could be established, this could also lead to other community disputes. By assisting and supporting the people in the development of a democratic society, equivalence, participation and non-exclusion could be ensured. The enforcement of a specific political system could result, however, in more tension and rebelliousness by the people, who may not find this kind of governance acceptable. This was exemplified after the US intervention in Iraqi politics during 2003 [62]. The US compelled the Iraqi state to adopt a democratic system by replacing the Sunni President Saddam Hussein with a predominantly Shia administration [63-66]. This resulted in the oppression and exclusion from the government of Sunni Iraqi people, which ultimately caused tension and aggravated the rebellious behaviour by the Iraqi people [64-67]. Negative experiences such as the US intervention in Iraq have created strong opposition towards external intervention in the Middle East. In order to avoid bringing about such situations, a human security programme recognizes the importance of participation and input from the local population [28]. In fact, such participation is recognized as being "vital to the successful implementation and sustainability of human security" [28]. It is recognized by the International Commission on Intervention and State Sovereignty (ICISS) that the international community has a role to play in safeguarding human security where local attempts fail: 
"The concept of human security—including concern for human rights, but broader than that in its scope-has also become an increasingly important element in international law and international relations, increasingly providing a conceptual framework for international action. Although the issue is far from uncontroversial, the concept of security is now increasingly recognized to extend to people as well as to states. It is certainly becoming increasingly clear that the human impact of international actions cannot be regarded as collateral to other actions, but must be a central preoccupation for all concerned. Whether universally popular or not, there is growing recognition worldwide that the protection of human security, including human rights and human dignity, must be one of the fundamental objectives of modern international institutions" [38,68].

In order to prevent controversy, however, it may be suggested that regional states should first be called upon to act as agents of human security. International states which do not understand the political and social circumstances of a particular state could then intervene only if local and regional assistance to implement human security has failed.

\section{Conclusion}

In Syria, state violence coupled with attacks by non-state extremist groups such as ISIS has resulted in human rights violations that "shock the conscience of the human mind". In response, the international community has been launching airstrikes with the objective of eliminating these threats [2224]. Similarly, neighbouring states have been dispatching state armed forces to assist with this mission on the ground [13]. However, the use of force is a short-term response that continues to affect the interests of innocent people [44].
Millions of people are forced to abandon their homes to escape the conflict and its effects [69]. For that reason, a long term response that could be used in response to this conflict would be the implementation of a human security programme [44]. The use of such a programme does not mean that the use of force should be abandoned in totality [29], but instead, as indicated by Kees Homan, that force be used alongside human security as a means of enforcement where it is permissible under international law [29]. This being said, state armed forces can assist in strengthening law and order, for example [29].

A human security programme addresses a variety of insecurities [28] which threaten the "survival, livelihood and dignity of people and communities" [27], and it focuses on eliminating these threats in order that the general population may attain freedom of fear and want [39]. Human security, as a people-centred approach, recognises that the security of people should be a priority $[6,43]$, and as a result it endeavours to protect refugees by obliging states to protect these asylum seekers [18].

An objective of human security is to empower the people by building the capacity of the government and local institutions to provide services. It also encourages people to make important decisions and to take control of their own lives $[27,28]$. Furthermore, the capacity of police and other security forces to deal with such threats is strengthened in order to enable them to protect the people and their communities.

Specifically, with regards to Syria, intervention methods could include disarming and demobilising armed groups. In addition, the people could be assisted to move from accepting authoritarianism in government to insisting on democracy [28]. This transition will address the root causes of the crisis, as it was their exclusion and oppression that resulted in the development of this civil war in the first place.

\section{References and Notes}

[1] Bennett AM. Islamic history \& Al-Qaeda: A primer to understanding the rise of Islamist movements in the modern world. Pace International Law Review Online Companion. 2013;pp. 316-370.

[2] Malantowicz A. Civil war in Syria and the new wars debate. Amsterdam Law Forum. 2013;5:52-60.

[3] "We've never seen such horror": crimes against humanity by Syrian security forces. Human Rights Watch. 2011 Jun 01;Available from: https://www.hrw.org/report/2011/06/01/weve-never-seen-suchhorror/crimes-against-humanity-syrian-security-forces.

[4] World report 2013: Syria. Human Rights Watch. 2013;Available from: https://www.hrw.org/world-report/2013/country-chapters/syria.

[5] Nassief I. The Campaign for Homs and Aleppo. Washington, DC, USA: Institute for Study of War; 2014. Middle East security report 17.

[6] Kerkkänen A. The failure of the security paradigm in Syria: the human security perspective; 2014. Available from: http://www.fiia.fi/en/ publication/389/the_failure_of_the_security_paradigm_in_syria/.

[7] Hashim AS. The Islamic State: From al-Qaeda affiliate to Caliphate. Middle East Policy. 2014;21(4):69-83. doi:10.1111/mepo.12096.

[8] Cockburn P. The rise of Islamic State: ISIS and the new Sunni revolution. Verso Books; 2015.

[9] Mockaitis TR. The "new" terrorism: myths and reality. London, UK: Praeger Security International; 2007.

[10] McCants W. The ISIS apocalypse: The history, strategy, and dooms-

day vision of the Islamic State. New York, NY, USA: Martin's Press; 2015.

[11] Waltman G. Prosecuting ISIS. SSRN Electronic Journal. 2016;85:817-856. doi:10.2139/ssrn.2537044.

[12] Byman D. ISIS Goes Global: Fight the Islamic State by Targeting Its Affiliates. Foreign Affairs. 2016;95:76-85.

[13] Spencer R. The Complete Infidel's Guide to ISIS. Regnery Publishing; 2015.

[14] Sekulow J, Sekulow J. Rise of ISIS: A threat we can't ignore. Simon and Schuster; 2015.

[15] People internally displaced by conflict and violence. IDMC; 2015 Available from: http://www.internal-displacement.org/assets/library/ Media/201505-Global-Overview-2015/20150506-global-overview2015-en.pdf.

[16] UNDPadministrator visits Syrian refugees in Turkey. United Nations Development Programme; 2015. Available from: http://eurasia.undp.org/content/rbec/en/home/presscenter/ pressreleases/2015/4/23/undpadministrator-visits-syrian-refugeesin-turkey.html.

[17] UN and partners seek almost $\$ 500$ million to avert humanitarian disaster in Iraq. United Nations High Commissioner for Refugees; 2015. Available from: http://www.unhcr.org/5570632a6.html.

[18] O'Sullivan M. Human security and the protection of refugees in Africa. In: Abass A, editor. Protecting Human Security in Africa. Oxford, UK: Oxford University Press; 2010. pp. 155-175. 
doi:10.1093/acprof:oso/9780199578986.003.0008.

[19] Miller C. Border chaos: Europe reacts to Syrian refugee crisis; 2015. Available from: http://yaleglobal.yale.edu/content/borderchaos-europe-reacts-syrian-refugee-crisis.

[20] Syria crisis: ECHO factsheet. European Commission, European Civil Protection and Humanitarian Aid Operations; 2015. Available from: http://ec.europa.eu/echo/files/aid/countries/factsheets/syria_en.pdf.

[21] Hehir A. Humanitarian intervention: an introduction. Palgrave Macmillan; 2013. The answer to this question falls outside the scope of this note. The answer to this question falls outside the scope of this note.

[22] Obama B. Statement by the President; 2014. Available from: https://www.whitehouse.gov/the-press-office/2014/08/07/ statement-president.

[23] Obama B. Statement by the President; $2014 . \quad$ Available from: https://www.whitehouse.gov/the-press-office/2014/09/10/ statement-president-isil-1.

[24] Global coalition to counter ISIL. US Department of State; 2014. Available from: http://www.state.gov/s/seci/

[25] Operation Inherent Resolve. US Department of Defence; 2016. Available from: http://www.defense.gov/News/SpecialReports/0814 Inherent-Resolve.

[26] Schmitt MN. Legitimacy versus Legality Redux: Arming the Syrian Rebels'. Journal of National Security Law and Policy. 2014;7:139159.

[27] Human security approach. UN Trust Fund for Human Security. Available from: http://www.un.org/humansecurity/humansecurityunit/human-security-approach.

[28] Human security in theory and in practice: an overview of the human security concept and the UN Trust Fund for Human Security. UN Human Security Unit. Available from: http://www.un.org/humansecurity/sites/www.un.org.humansecurity/ files/human_security_intheory_and_practice_english.pdf.

[29] Homan K. The military and human security. Security and Human Rights. 2008;19(1):73-81. doi:10.1163/187502308784048582.

[30] Tadjbakhsh S, Chenoy A. Human security: Concepts and implications. Routledge; 2007.

[31] Abass A. An Introduction to Protecting Human Security in Africa. In: Protecting Human Security in Africa. Oxford, UK: Oxford University Press; 2010. pp. 1-18. doi:10.1093/acprof:oso/9780199578986.003.0001.

[32] United Nations Development Programme Human Development Report. New York, USA: United Nations Development Programme; 1994. doi:10.18356/87e94501-en.

[33] Thomas C. Global governance, development and human security: the challenge of poverty and inequality. Pluto; 2000.

[34] King G, Murray CJL. Rethinking Human Security. Political Science Quarterly. 2001;116(4):585-610. doi:10.2307/798222.

[35] Hampson FO, Daudelin J. Madness in the multitude: Human security and world disorder. Don Mills, Canada: Oxford University Press; 2002.

[36] Paris R. Human Security: Paradigm Shift or Hot Air? International Security. 2001;26(2):87-102. doi:10.1162/016228801753191141.

[37] Liotta PH, Owen T. Why human security? Whitehead Journal of Diplomacy and International Relations. 2006;7:37-54.

[38] Alkire S. A conceptual framework for Human Security; 2003. Available from: http://www3.qeh.ox.ac.uk/pdf/crisewps/workingpaper2.pdf.

[39] Human security now. Commission on Human Security; 2003. Available from: http://www.un.org/humansecurity/sites/www.un.org. humansecurity/files/chs_final_report_-_english.pdf.

[40] Mahmud H, Quaisar MM, Sabur A, Tamanna S. Human security or national security: the problems and prospects of the norm of human security. Journal of Politics and Law. 2008;1:68.

[41] Roznai Y. The insecurity of human security. Wisconsin International Law Journal. 2014;32:95-101.

[42] Human Development Report 2009. United Nations Development Programme; 2009. doi:10.18356/9d335cec-en

[43] Arab human development report: Challenges to human security in the Arab Countries. United Nations Development Programme; 2009. doi:10.18356/9d335cec-en.

[44] Human Development Report 1993. United Nations Development Programme; 1993. doi:10.18356/3792591a-en.
[45] Human security at the UN. UN Human Security Unit; 2012. Available from: http://www.humansecuritynetwork.net/documents/125374024/ 128230464/UN+Human+Secrity+Brochure+-+UN+HS+Unit

[46] The focus of this note is not on the implementation aspects as such and will therefore not provide an extensive analysis thereof. The different phases will therefore only be identified and briefly explained.

[47] Designing a human security programme/project. UN Human Security Unit. Available from: http://www.un.org/humansecurity/sites/www.un. org.humansecurity/files/applying_the_human_security_approach_in_ programmes_and_projects.pdf.

[48] The aim with this paragraph is not to investigate in detail the implementation of a Human Security programme in the DRC and Kosovo as it does not fall within the scope of this note. The two examples are merely used to illustrate the applicability of a Human Security programme in conflict situations.

[49] Flaubert C. Democratic Republic of the Congo-Evaluation of UNDP assistance to conflict-affected countries; 2006. Available from: http: //web.undp.org/evaluation/documents/thematic/conflict/DRC.pdf.

[50] Dulic D. Peace Building and Human Security: Kosovo Case. Global Governance. 2007;13(3).

[51] Human security project proposal. United Nations Kosovo Team; 2012. Available from: http://www.ks.undp.org/content/dam/kosovo/ docs/FK_Ob/HSFT_PRODOC.pdf.

[52] Singh J. Problem of ethnicity: the United Nations and Kosovo crisis. Unistar; 2008.

[53] Human Development Report. United Nations Development Programme; 2004. doi:10.18356/68b83600-en

[54] Oler A. Brief introduction to the Sunni-Shi'ite Struggle: Six key points. Reporter. 2007;35:2-16.

[55] Hellyer H. Jihad Re-Examined-or Jihad Repaired: Bellum lustum in a World of International (Dis)-Order. Santa Clara Journal of International Law. 2012;10:35.

[56] Bereczki RL. From Islam to Jihad recognition. AGORA International Journal of Juridical Sciences. 2015;pp. 5.

[57] Berti B. The Syrian refugee crisis: Regional and human security implications. Strategic Assessment. 2015;17(4):41-53.

[58] Brown A. Just wait-Islamic State reveals it has smuggled thousands of extremists into Europe; 2015. Available from: http://www.express.co.uk/news/world/555434/Islamic-StateISIS-Smuggler-Thousands-Extremists-into-Europe-Refugees.

[59] Haroun AB. "Prize operatives": ISIS smuggling fighters into Europe disguised as refugees; 2015. Available from: https://www.rt.com/ news/259581-isis-militants-refugee-boats/.

[60] Lassan S. Protecting the children and youth of Syria: human security threats and their consequences; 2014. Available from: http://crdc.gmu.edu/wp-content/uploads/2014/09/ProtectingtheChildren-of-Syria-Human-Security-Threats-And-TheirConsequences-1.pdf.

[61] UNDP response to the Syria crisis: supporting humanitarian livelihoods and community resilience in Syria, Lebanon and Jordan. United Nations Development Programme; 2013. Available from: http://www.undp.org/content/dam/undp/library/corporate/ fastfacts/english/FFSyriaJune72013.pdf.

[62] Bush GW. President Bush outlines Iraqi threat; 2002. Available from: http://georgewbush-whitehouse.archives.gov.

[63] Iraq: a population silenced. Bureau of Democracy; 2002. Available from: http://2001-2009.state.gov.

[64] Trumbull IV CP, Martin JB. Elections and Government Formation in Iraq: An Analysis of the Judiciary's Role. Vand J Transnat'l L. 2011;44:331-388.

[65] Katzman K, Humud CE. Iraq: politics and governance; 2016. Available from: https://fas.org/sgp/crs/mideast/RS21968.pdf.

[66] Rollins JW, Peters HM. The Islamic State-frequently asked questions: threats, global implications, and U.S. policy responses; 2015.

[67] International Crisis Group; 2013. Available from: https://www. crisisgroup.org/.

[68] The responsibility to protect: report of the International Commission on Intervention and State Sovereignty. International Commission on Intervention and State Sovereignty and International Development Research Centre (Canada); 2001.

[69] Refer to Section 3.1 for displacement figures. 